\title{
The Promise of Artistic Research in the Asia Pacific
}

\author{
Danny Butt (แดนนี่ บัตต์) \\ Associate Director (Research), Victorian College of the Arts, University of \\ Melbourne, Melbourne, Australia \\ butt@unimelb.edu.au
}

\begin{abstract}
Artistic research has sought to gain academic legitimacy through adapting to scientific methods, while also retaining the mandate of the humanities in the reproduction of culture. In both cases, Western epistemologies have structured what constitutes knowledge and how it is circulated and shared. The contemporary university is far more connected to its local environment, bringing the potential of engaging broad publics in the life of the institution. Innovation and experimentation with local artistic forms is one way that artistic research can powerfully animate the 21st century university mission in the Asia Pacific.
\end{abstract}

\section{Keywords}

artistic research - Asia-Pacific - colonisation - universities - local knowledge

\section{บทคัดข่อ}

ความสำเร็จของงานวิจัยด้านศิลปะในเอเชียแปซิฟิก

หนทางที่จะทำให้งานวิจัยด้านศิลปะได้รับการยอมรับทางวิชาการ คือการประยุกต์ใช้วิธีการทาง วิทยาศาสตร์ แต่ก็ยังคงรักษาแก่นทางมนุษยศาสตร์ไว้ในการผลิตซ้ำด้านวัฒนธรรม ในทั้งสอง กรณี ปรัชญาการค้นหาความจริงของโลกตะวันตกก็มีส่วนในการสร้างระบบความรู้ และระบบการ เผยแพร่และแลกเปลี่ยนความรู้นั้น อุดมศึกษาในปัจจุบันเข้าไปผูกพันเชื่อม โยงกับท้องถิ่นมาก และ ได้นำสมรรถนะของโลกนอกอุดมศึกษาเข้ามาในรั้วอุดมศึกษา นวัตกรรมและการลองผิดลองถูก ในด้านศิลปะพื้นบ้านเป็นหนทางหนึ่งที่จะทำให้งานวิชาการทางด้านศิลปะเข้ามาช่วยทำให้พันธ กิจของอุดมศึกษาในศตวรรษที่ 21 ในภูมิภาคเอเชียแปซิฟิกเป็นไปอย่างเข้มแข็งและมีชีวิตชีวาได้ 
The eighteenth Festival Lima Gunung was held at Tutup Ngisor on the slopes of Mt Merapi, Yogyakarta, Indonesia, in 2019. Festival initiator Pak Sutanto Mendut noted in his remarks that the region's historical flow of knowledge and expertise precedes and exceeds the Indonesian nation state. Before the arrival of Muslim traders and European colonisers, Central Java was settled by both Hindu and Buddhist peoples, as part of an extended community that reached more north toward what is now known as Thailand and Cambodia, rather than east-west across the rest of the archipelago now known as Indonesia.

The renewed force of indigenous knowledges across the globe reflects the efforts of oppressed peoples to survive in settler-colonial and postcolonial nation-states that have sought their destruction. This work has now extended to a broader critique of Western neocolonial discourses embedded in the synchronised economic structures known as neoliberalism, which also circle the globe. The international emergence of indigenous cultural activism proposes a new way of thinking about regional alliance which does not conform to modernist legacies of the nation state or "free market", underwritten by the doctrine of discovery. Central to the critique of neocolonialism and developmentalism is a revised temporal orientation for research. C. P. Snow, the scientist turned science propagandist, noted in 1971 that the choice between scientific research and humanities knowledge is a stark one:

One [science] is cumulative, incorporative, collective, consensual, so designed that it must progress through time. The other [humanities] is noncumulative, non-incorporative, unable to abandon its past but also unable to embody it. The second culture has to be represented by negatives, because it is not a collectivity but is inherent in individual human beings. That means it possesses qualities which the scientific culture does not and never can; and, on the other hand, since there is a principle of mutual exclusion, it loses by its nature the diachronic progress which is science's greatest gift to the mind of man (Snow 1971, 96).

Colonial knowledge brought Christian visions of future salvation through domination of territory and departure from the past; but to call its scientific legacy a "gift" is to perhaps adopt modernisation altogether too uncritically. The terms of the gift of scientific knowledge prohibited communities in settler colonial states from retaining their customary forms of knowledge and enquiry, practices that were seen by Europeans as threatening to the social order. The effect of this rationality on our conceptions of research are well captured by anthropologist Robin Horton his 1967 article "African Traditional Thought and Western Science," which outlined the reasons why the modern scientist 
must dismiss the magical notions of indigenous knowledge and the idea that words and concepts have power over the things they represent. A scientist would not even test the validity of "absurd and alien trappings of traditional thought," he says, because there are deeper grounds for rejection of magical behaviour that "make testing beside the point" (Horton 1967, 159). Indigenous knowledge is placed outside of the ratio of scientific knowledge - it cannot be compared with or contrasted against science through the use of scientific methods. For Horton scientific methods instead require "faith" that "there must be some anchor, some constant reality" (Horton 1967, 160). The alternative of a world in flux is too "intolerable" or "horrific" for Horton to countenance. The job of scientific knowledge production is to deliver consensus around tolerable human reality, which nevertheless only consists within the Western tradition of reason, while other modes of thinking must be dismissed out of hand. This unease with change and transformation is why science education is typically uninterested in the history of science, with Stephen Brush (1974) going as far as to say that teaching the history of science might only sap the confidence of students in finding this consensus reality and make them worse scientists.

The recent history of artistic research in the Anglo-Saxon world has largely been a quest for acceptance into a science-dominated paradigm of university knowledge, which must be both universal and specifiable in advance - today that specification should not only be specifiable but be quantifiable. However, the STEM paradigm has had little capacity to engage indigenous knowledge except as resources for extraction - indigenous knowledge is never permitted to be the all-encompassing operating "software" that languages by definition offer the human. The initiatives around artistic research have therefore often remained wedded to a scientific modernisation narrative, with Anglo researchers and critics such as myself invited in to share the beneficent resources of the West that can assist artists to retain their home in the global university form.

Artistic research ultimately does not need to police the terms of cultural enquiry in the same way as the sciences, as its connection to the humanities allows multiple histories and cultural logics to overlap; and the results of its enquiry do not need to be made available only in alphabetic language. Extending from Snow, we can see that artistic research escapes the dichotomy of the "two cultures" as in table 1.

Artistic research, in its multiplicity and non-alphabetic form, is therefore a natural framework in which to explore knowledge in multicultural societies that have a range of approaches to how knowledge is registered, understood, and shared. Potentially, artistic research provides a space that can welcome 
TABLE 1 Scientific Research, Humanities Research, and Artistic Research

\begin{tabular}{|c|c|c|c|}
\hline & $\begin{array}{l}\text { Scientific Research } \\
\text { (Snow) }\end{array}$ & $\begin{array}{l}\text { Humanities Research } \\
\text { (Snow) }\end{array}$ & Artistic Research \\
\hline $\begin{array}{l}\text { Knowledge } \\
\text { model }\end{array}$ & $\begin{array}{l}\text { Cumulative; a } \\
\text { "stock of } \\
\text { knowledge" that } \\
\text { can be added to; } \\
\text { reliable; replicable; } \\
\text { positive; "the truth" }\end{array}$ & $\begin{array}{l}\text { Non-cumulative; } \\
\text { knowledge is singular } \\
\text { within a genre; ethical } \\
\text { and interpretive; } \\
\text { negative (insight involves } \\
\text { learning to remove } \\
\text { inappropriate lenses) }\end{array}$ & $\begin{array}{l}\text { Non-cumulative; } \\
\text { materials-based } \\
\text { (extra-human); } \\
\text { potentially extreme } \\
\text { singularity within a } \\
\text { meta-genre of artistic } \\
\text { production }\end{array}$ \\
\hline Social Model & $\begin{array}{l}\text { Consensual and } \\
\text { Collective; the } \\
\text { "modest witness" }\end{array}$ & $\begin{array}{l}\text { Individualised in a } \\
\text { community of readers; } \\
\text { the "author" }\end{array}$ & $\begin{array}{l}\text { Individualised in a } \\
\text { scene of action; the } \\
\text { "producer" }\end{array}$ \\
\hline Temporality & $\begin{array}{l}\text { Diachronic; } \\
\text { evolutionary and } \\
\text { future-oriented; } \\
\text { requires } \\
\text { historicisation }\end{array}$ & $\begin{array}{l}\text { Diachronic; } \\
\text { historically-bound }\end{array}$ & $\begin{array}{l}\text { Synchronic - } \\
\text { knowledge happens } \\
\text { in the moment of } \\
\text { encounter/viewing; } \\
\text { requires critical } \\
\text { interpretation and } \\
\text { historicization }\end{array}$ \\
\hline
\end{tabular}

indigenous knowledges which provide flexible models of space and time for contemporary and future action that can help us understand the specificity of our place in the world.

We can remember here the late Tongan scholar Epeli Hau'ofa's (1994) concept of the Pacific as a "Sea of Islands" rather than a set of small island statesa vast oceanic continent of historical and contemporary movement of people and practices. Gayatri Chakravorty Spivak (2006) reminds us that local knowledge by definition is distinctive on the basis of language - while the term "culture" has equivalents in non-European languages, those terms do not do the same work of delineating the space between the sacred and the profane that the English word does. So too, we can advocate for the necessity of sharing culturally specific methodological frames in a regional network outside of the European cultural perspective which implicitly takes an extractive approach to cultural difference. 
For example, in Yogyakarta Indonesia, the recent work of KUNCI Cultural Studies (http://kunci.or.id) in their School of Improper Education shows how art-based inquiry can be explored outside the developmentalist paradigm. The initial elements of the school involved experiments in equalisation of the power relation between teacher and student attributable to Rancière. But more recently, they have also found concepts of local resonance that also deconstruct the instrumental model of learning. These include Nyantrik, a Javanese mode of apprenticeship where the teacher becomes the student; and Turba (Turun ke Bawah) a more recent adaptation of socialist realist aesthetics that proposes learning from below.

Such organising principles are difficult if not impossible to stage within an English language context. They are principles that relate to the whole structure of knowledge, rather than being something that one should know about in an anthropological catalogue of terms. We can see the difficulties faced in articulating these values into, for example a national university research assessment regime. Perhaps this can sensitise us to how investment in state-backed research assessment regimes can lead to a capture of our methodological imaginary by nationalist priorities that preclude continuity with extra-national or intranational cultural forms.

\section{1 \\ Challenges to the $21^{\text {st-Century University }}$}

The most pressing question facing universities is their relevance of its research to the broader political economic structure, reflected in the shift from basic science to applied research. In classical Science and Technology Policy, the innovations of university research required a process of "knowledge transfer" to reach a broader community, but it was understood that the dissemination of knowledge was largely unidirectional. It was once the case that investments from science and technology policy to a relatively autonomous university sector assumed that universities would naturally disseminate this knowledge out to a broader nation. Under the colonial paradigm, universities were seen as not only contributors to human knowledge, but the educators and engines of a workforce relevant for a nation's technical economy. Over the second half of the 2oth century, many governments funded tertiary education as a critical component of a knowledge-based economy. As we approach the third decade of the 21st century, however the practices of scientific research and universitybased knowledge production have lost some of their force.

However, increasingly, investments in tertiary education and research require more specific and frequent evaluation and justification. Longer term 
platforms of research are harder to sustain, as research competes with other university investments to generate measurable impact and value. Health is one of the areas where we can see this transformation, with the broad growth in consumer health technologies that have not been hatched from a research lab in a hospital or university's medical faculty, but from device manufacturers and the burgeoning health technology sector.

Today, universities compete among other private and public entities to be an authoritative source of information. This has been facilitated by a change in the structure of media: rather than the university holding the world's archive of authoritative knowledge in its libraries, knowledge today exists in a broader, privately run information network that crosses institutional and national boundaries. As Jacques Derrida (2002) pointed out, the arrival of the world wide "data bank" for knowledge fundamentally transforms the mission of the university from a place that students and researchers come into for knowledge, to one where they learn new techniques of thinking and engaging the world. What universities across the world are grappling with today is the problem of "public value" and how to renew engagement with public life when universities are no longer the natural source of knowledge, and many of the political and economic structures that have previously looked for university knowledge have dissipated.

Artistic research in our region addresses this conjuncture in the academy in powerful ways:

Firstly, the outcomes of artistic research need no "translation" to a broader world. There is an audience for artistic inquiry that involves both academic experts and a broader general public, who visit galleries, performance venues, and cinemas where the results of artistic research are shown. Where traditional research and innovation models have seen the increasing porosity of universities as a problem, artistic research welcomes these interlopers as new audiences and participants in the research. Such an inclusive space is not only an efficient way for universities to demonstrate impact and public value, but the ethic of inclusion builds community within and outside the university.

Secondly, as we have seen, although the European settler-colonies aimed to suppress traditional knowledge in the modernist era, communities in the Asia Pacific region have diverse knowledge systems that do not conform to the monotheistic scientific paradigm of a flat global world of knowledge. Local knowledges are embedded in song, dance, music, and other formats outside of 
the book. A renewed focus on these traditions is allowing communities renewed access to customary modes of intergenerational knowledge transfer that are central to place-based identities. Europe saw these knowledges as incompatible with its own role as organiser of the world's knowledge, with Asiatic modes of knowledge production of interest only as an anthropological object of study. However, in the Asia Pacific region it has been possible for people to work with scientific and indigenous knowledge systems together in a syncretic mode, and the question now is how to articulate this in a global network.

Through the late 2oth century, most science and technology policy focussed on national economies and infrastructure. In today's global world, the possibility of stronger regional alliances has returned to the fore, along with a greater understanding of our shared histories. Universities have always been sites of cosmopolitan exchange, allowing us to understand our place on the planet in a broader context. As many countries struggle with a renewed articulation of cultural nationalism and prejudice, our institutions have the opportunity to foster new forms of collaboration in artistic research that can keep the spirit of regional collaboration alive.

\section{References}

Brush, Stephen G. 1974. "Should the History of Science Be Rated X?" Science 183, no. 4130 (March): 1164-72.

Derrida, Jacques. 2002. "The University without Condition." In Without Alibi, translated by Peggy Kamuf, 202-37. Stanford: Stanford University Press.

Hau'ofa, Epeli. 1994. “Our Sea of Islands.” The Contemporary Pacific 6, no. 1: 148-61. Horton, Robin. 1967. "African Traditional Thought and Western Science." Africa:Journal of the International Institute of African Languages and Cultures 37, no. 2: 155-87.

Snow, C. P. 1971. "The Case of Leavis and the Serious Case." In Public Affairs, edited by C. P. Snow, 81-97. London: Macmillan.

Spivak, Gayatri Chakravorty. 2006. "Culture Alive." Theory, Culture \& Society 23, no. 2-3: (May):359-6o. 